\title{
韓国清州市における血縁組織の形成と変容 全州崔氏の花樹会を事例として——
}

\author{
斎藤久美（東京学芸大学大学院生）
}

\begin{abstract}
本研究は, 韓国の地方中心都市である清州市を対象とし，都市における血縁組織の形成とその変容を，村 落から都市への人口移動との関連加ら明らかにすることを目的とした．韓国の都市における血縁組織の形成 は， 1960 年代以降，首都ソウルに人口が集中するとともに同族集落からの転入者によって，ソウルなどの 大都市に形成される動きがみられるようになった，清州市の血緑組織は，清州市への人口集中が著しくなっ た 1970 年代以降活発に形成されたという：一方，清州市の血縁組織は，1970 年代に忠清北道内の同族集落 から清州市に転入した経済的・社会的成功者たちを中心に，同族集落との連絡を補うために形成された。そ の後, 都市の血縁組織は, 各同族集落加らの転入者を会員に迎え入れ成長したが，その中で，就職の斡旋や 住居地の紹介など，転入者の都市定着支援などの役割も補う例ああった．都市の血縁組織は都市居住者が増 大するにしたがって, 都市住民のニーズに応じ, 血縁組織が細分化されるなど, 社会状況に応じて変容し続 けている.

キーワード：韓国，清州市，血縁組織，同族集落
\end{abstract}

\section{I はじめに}

1. 研究の目的と従来の研究

韓国社会における同姓同本に対する思想は，社会 組織や家族制度をはじめ，さまざまな社会事象に大 きな影響を与えてきた. 同姓同本とは, 姓と男系祖 先の発祥地である本貫とが同一であることを表す. 同本不婚の思想は，今日まで強い婚姻規制となり， 養子においても同姓同本の近親者内であり，さらに 子の世代に該当する男性が選択された（服部 1975）. また，同姓同本の人々によって形成された同族集 落1) は韓国特有の村落であり，韓国社会の特徴を 最む端的に表す事象であると善生（1933）により指 摘されている.

韓国の血縁組織 2) の研究は，1920～1930 年代に かけて行われた善生永助らによる集落調査により本 格的に始まった。 その後, 村落における血縁組織の 研究が盛んとなり，同族集落を対象とする実証的な 研究の中で, 社会人類学, 社会学などの分野におい て祖先祭祀の機能を中心に, 多くの蓄積を生んだ (李・末成 1973；金 1974；嶋 1976, 1978; 伊藤
1987）。この中で崔（1979）は，1950１960 年代に かけて本格的な同族集落調査を行い，血縁組織の機 能が同族集落内のみに限定されず，同族集落を超え て展開するあのであることを指摘し, さらに都市に 形成されつつあった血縁組織についであ留意するこ とを提唱した。

都市に打ける血縁組織は，魯（2000）が「1960 年以降, 韓国社会であ都市化が進み, 農村社会に基 盤を置く各種の同族集団は衰退する一方，都市にお いては，多くの同姓集団の組織化を始めるようにな った」と指摘するように，1960 年以降，都市にお いて次第に形成され増加していく，李（1971）は, 工業化ならびに都市化に伴う家族と血縁との関係の 変化を，それぞれの意識㧍よび行動の面から考察し， 都市における血縁研究の必要性を主張した. 李 （1980）は，血縁というイデオロギーが都市におい て消滅するのではなく, 補強され拡大してきたこと を明らかにした。魯 $(1992 ， 1994 ， 1997 ， 1998$, 2000）は，血縁組織の形成およびその多様な変容を， ソウルの都市化の諸局面と関連付けて実証的に研究 し，韓国社会における血縁組織の意義を明確にする 
ことを試みた。

また韓国における村落から都市への人口移動で, 村落の社会変容に大きな影響を及ぼすチェーン・マ イグレーションについては, 李 (1984) と鄭 (1988) などの研究がある（金 1995）。李（1984）は同族集 落内の強い血縁的結合が都市への人口移動の初期段 階にはその動向を抑制するが, 人口移動がある程度 進行すると, 逆に血縁的結合は強力なパイプライン として作用し，都市への人口移動を促進したことを 明らかにした。鄭 (1988) は, 忠清北道清原郡 の三つの村落を事例に，人口移動のメカニズムを明 らかにし, 韓国の人口移動は家族構成員によるチェ ーン・マイグレーションが一般的であることを実証 した。 そして，チェーン・マイグレーションによる 移動は, 転入先の都市内に出身地の血縁組織をその まま維持させる場合が多いことを示唆している.

これらの先行研究は, 都市における血縁組織が同 族集落からの転入者によって形成されたことを指摘 している. しかし，血縁組織と母村である同族集落 との関係の変化, 特に都市への人口移動の変化との 関わりについては明らかにされていない，また，い ずれあソウルなど大都市を対象とした研究である.

しかし, ソウルは韓国の首位都市であり, ソウルの 事例のみをむって韓国都市の血縁組織の一般性を述 べることはできない.

そこで本研究は, 韓国の地方中心都市である 清”州市を対象とし, 都市における血縁組織の形成 とその変容を, 村落から都市への人口移動との関連 から明らかにすることを目的とする.

\section{2. 研究方法}

本稿ではまず, II で研究対象地域である清州市と 清州市への人口集中の背景について概観する.さら に, 清州市の血縁組織を同族集落との関係を指標に 類型化する. 血縁組織の多くは公的機関への届出を 不要とする任意組織であるため, 清州市に存在する
すべての血緑組織を把握することは困難である。こ のため, 電話帳を用いて血縁組織の所在を調べた。 確認し得た血縁組織を個別訪問し, 聞取り調査を行 った。ささらに電話帳には掲載されていないが, 現地 調査において看板を確認できた血緑組織についても, 聞取り調查を行った. 現地調査は 1999 年 $7 \sim 8$ 月お よび 2001 年 6 月に実施した.

III では全州崔氏系の血縁組織を事例に, 転出元の 同族集落との関係から，血縁組織の形成とその変容 を明らかにする．血縁組織の分析資料は 1999 年 8 月と 2001 年 6 月とのアンケート調査によって得た. 全州崔氏清州・清原花樹会会員へのアンケートは, 43 人に対して実施し, 30 人より有効回答を得た. 実施した内容は, 氏名, 年齢, 派, 現住所, 出身地, 家族構成, 組織での役職, 入会年, 参加回数, 血縁 組織への参加利点についてである. 2001 年 6 月の 実施内容は, 上記に加え, 清州市への転入時の年齢 と転入理由, 入会方法についてである. 同族集落に ついては 2001 年 6 月および 2002 年 3 月に聞取り調 查を実施した.

\section{II 清州市の人口増加と血縁組織の形成}

1. 清州市の人口増加とその要因

清州市は首都ソゥルの南南東約 $120 \mathrm{~km}$ に位置し, 2000 年現在人口約 57 万人で, 忠清北道の道庁所在 地である（図 1).1908 年に憅”州から道庁が移転さ れたことにより, 清州は忠清北道の中心都市となっ た（忠北大学校人文科学研究所 1997).

日本統治時代終結後の 1946 年, 漢江以南最初の 私立大学である清州商科大学 (現, 清州大学校) が 設立された.さらに 1951 年に忠清北道で最初の国 立初級農科大学 (現, 忠北大学校) が設立されたこ となどにより, 清州市は教育都市として発展した。 これら教育機関の集積は，進学を目的とした青少年 層が忠清北道各地から清州市に転入する一つの要因 となった。 


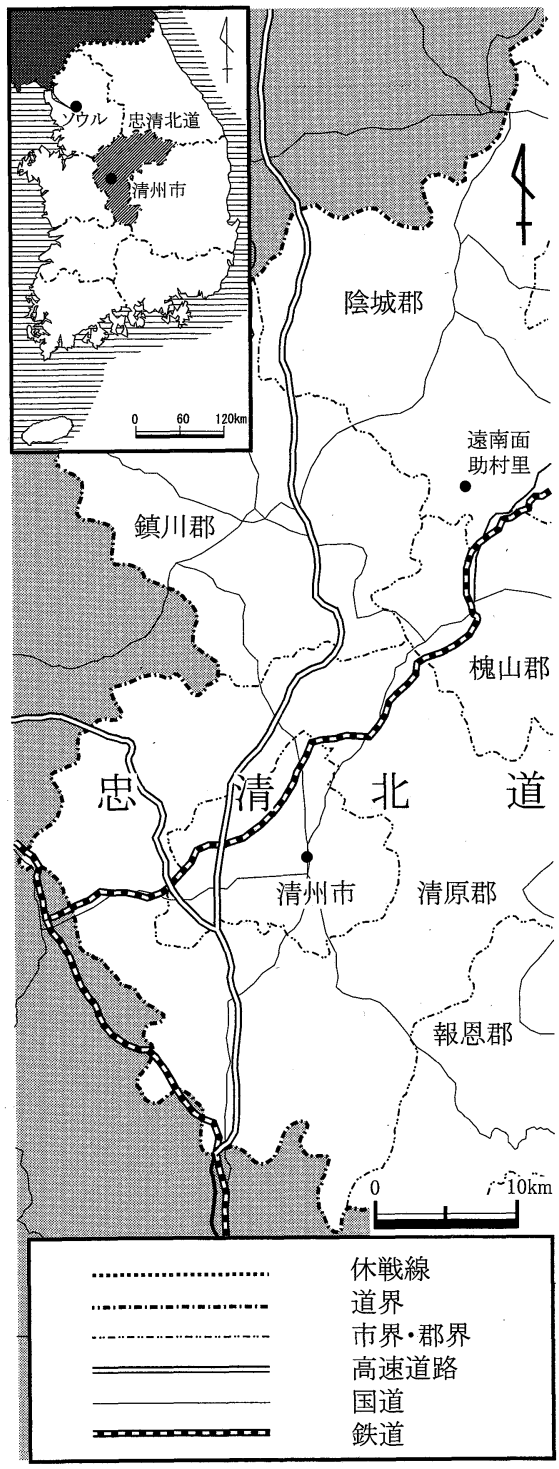

図 1 研究対象地域

Fig. 1 Study area

1958 年，京釜線と中央線とを連結する産業鉄道 の忠北線が全線開通する．また政府の首都圏からの 人口・工場の分散政策と地方の工業育成策により， 1972 年から清州工業団地の造成が開始された。清 州工業団地の造成は清州市の就業需要を高め, 清州 市周辺はもちろん，忠清北道各地から清州市に就業 を目的とする青壮年者が転入し，第二，三次産業従

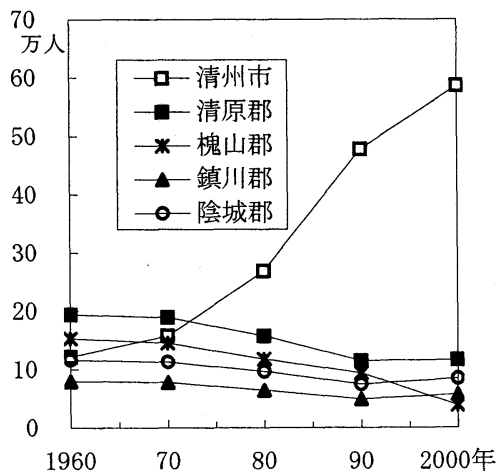

図 2 清州市および近隣郡の人口推 移（1960～2000 年)

清州市のデータには, 編入された 1966 年以前 の旧清原郡四州面, 1985 年以前の同郡江西面 のデー夕を含み, 可能な限り現在の行政区域で 集計した.

（1960 年は 『人口住宅国政調查』，1970 年以降

は『総人口と住宅調查報告』により作成).

Fig. 2 Population change in Cheongju and its vicinity (1960-2000)

事者数が増加した（権 1978）。このように 1960 年 以降，清州市の近隣郡の人口が緩やかに減少してい る一方で，清州市の人口は 1970 年に約 15 万 8000 人, 1980 年には 1.7 倍の約 26 万 9000 人に, 1990 年にはさらに 1.8 倍の約 47 万 8000 人になり，1970 年代以降，急激な増加を示した（図 2).

\section{2. 忠清北道の同族集落}

清州市および周辺の同族集落の記述は, 1760 年 に編纂された『輿地䒚書』の清州誌が最初である。 これによれば当時，清州市周辺において 54 の同族 集落が存在していたと推測される。しかし，これは 古記録を収録したあのであり，実際に同族集落が確 認されたのは，1930 年代に入ってからである．善 生（1935）によれば，1933 年当時，忠清北道には 507 の同族集落が存在し，さらに現清州市域および 清原郡域に 126 の同族集落が存在したとされている. また道誌および各市誌，郡誌も，同族集落について は独自に調査され，まとめられているあのが多い， 上記の善生（1935）㧍よびこれら各道・市・郡誌を 
基に，さらに個別訪問の際，あらたに知り得た同族 集落を加え, 忠清北道の同族集落の分布を示した (表 1)。清州市に同族集落を形成していた血緣集団 は五つしかなく，ほとんどの血縁集団が清州市外に 同族集落を形成していたことがわかる.

\section{3. 清州市の血縁組織}

清州市の血縁組織は, 1999 年と 2001 年の現地調 査では 35 を確認した（表 2)。これらの血縁組織と 同族集落との関係を調べた結果, 32 の組織が清州 市以外の同族集落に存在していた. 同族集落の立地 は清州市をとりまく清原郡のみならず, 忠清北道全 域に広がり，これらの同族集落からの転入者たちに よって清州市の血縁組織が形成されたものと考えら れる.

次に清州市の血縁組織を聞取り調査に基づいて整 理, 類型化した (表 3). A タイプは古くから旧清 州邑周辺に同族集落を形成し，その中に血縁組織を 形成していた。しかし，清州市域の拡大により同族 集落が市域の中に取り込まれ，同族集落に存在して いた血縁組織むそのまま都市に存続した.このため, A タイプは 20 世紀以前に形成されたと考えられる. 組織の加入条件あ同姓同本であるだけではなく, 同 派3）でなければならず, 血縁組織の加入も義務化 されている．また同族集落が住宅地に転用されるに 従い, 共有財産であった林野や土地を売却している. この売却金を資本として旧同族集落域内にビルを建 設し，ビルの賃貸料などを血縁組織の運営費用に当 てた。このため, 共有財産であるビルの維持・管理 者として役員がビルに常勤する．役員は訪問する会 員の相談に対応している，会合は年に 1 回程度で, 参加者数は 100 人以上である. 会合では組織の運営 方針，事業に関する議論が行われ，組織の活動屯宗 事4）に関することが中心である.

B タイプの形成時期は 1945 年以降, 特に 1970 年 代以降に集中し，清州市に転入した人々を中心に形
成された血縁組織である。このため, B タイプは加 入・脱退が同姓同本であれば会員の任意であり，共 有財産を持たないため，会費や会員からの賛助金な どで組織の運営費用を賄っている，また，組織が所 有する建物がないため, 組織の事務所は会員からの 提供を受けた場合を除いて，ほとんぞが常勤役員を 置かず，自営業を営む会員の建物に併設されている. 形成時の目的は宗事に対する補助的な役割を果た すためであった．これは宗事に関する事業の一つで ある族譜 5) 編纂が大きく関わっている．血縁集団 は各自の血統の正当性を主張するために族譜編纂を 行っているが，ごれには名前や出生年をはじめ，学 歴，職歴などの個人情報が必要不可欠である，この ため, 都市居住者たちの情報を収集する必要性から, 清州市への人口集中が顕在化した 1970 年以降, 血 縁組織の形成が活発になったと考えられる。

現在の活動としては，会合のタイプから中心とな る二つの活動が考えられる. 年に $1 \sim 2$ 回程度の会 合では, 参加者数 100 人以上で, 組織の運営, 宗事 事業に関して議論が行われる。このため, 組織の中 心的活動は宗事に関することである.しかし月に 1 回程度の会合は, 参加者数 30 人前後の食事を伴う 小会合である点などから，活動の中心は会員間の親 睦の深化にあると考えられる. 組織の活動に旅行が 組み込まれているあのああり，このことからあ組織 のあう一つの中心的活動が親睦にあることは明らか である、このほかに, 転入者への職業や住居地の斡 旋などの都市生活の支援や奨学金, 災害見舞金, 冠 婚賛助金など都市居住者間の相互扶助としての役割 あ見出すことができる.

\section{III 血縁組織の形成亡変容 一一全州崔氏の花樹会を事例にして——}

\section{1. 全州崔氏花樹会の概要}

ここでは, 地方都市における血緑組織の典型例と 考えられる B タイプの中から, 全州崔氏の血縁組 
表 1 忠清北道における同族集落一覧

Table 1 List of lineage villages in Chungcheong-buk-do

\begin{tabular}{|c|c|c|c|c|c|c|c|c|c|c|c|}
\hline 姓氏・本貫 & 清州市 & 清原郡 & 忠州市 & 堤川市 & 報恩郡 & 沃川郡 & 永同郡 & 鎮川郡 & 槐山郡 & 陰城郡 & 丹陽郡 \\
\hline 慶州金氏 & & 0 & 0 & & 0 & 0 & 0 & 0 & 0 & 0 & 0 \\
\hline 全州李氏 & & & 0 & & 0 & 0 & 0 & 0 & 0 & 0 & 0 \\
\hline 密陽朴氏 & & 0 & & 0 & 0 & 0 & 0 & 0 & 0 & 0 & 0 \\
\hline 金海金氏 & & & 0 & & 0 & 0 & 0 & 0 & 0 & & 0 \\
\hline 慶州李氏 & & 0 & 0 & 0 & 0 & 0 & & 0 & & 0 & 0 \\
\hline 慶州崔氏 & & 0 & 0 & & 0 & 0 & & 0 & & 0 & \\
\hline 安東金氏 & & 0 & 0 & & & & & 0 & 0 & 0 & \\
\hline 坡平尹氏 & 0 & & & & 0 & & 0 & 0 & & & \\
\hline 晋州姜氏 & & 0 & 0 & O & 0 & 0 & 0 & 0 & & 0 & \\
\hline 清州韓氏 & 0 & & 0 & & & 0 & 0 & 0 & & & \\
\hline 高霊申氏 & & 0 & & & & & & 0 & & & \\
\hline 順興安氏 & & & 0 & & 0 & 0 & & 0 & O & 0 & 0 \\
\hline 光山金氏 & & & 0 & & & & & 0 & & 0 & \\
\hline 安東権氏 & & 0. & 0 & 0 & & & & 0 & & 0 & 0 \\
\hline 東萊鄭氏 & & 0 & & & & & 0 & 0 & & 0 & \\
\hline 順天朴氏 & 0 & 0 & & & & & 0 & 0 & & 0 & \\
\hline 文化柳氏 & 0 & 0 & & 0 & & 0 & & 0 & O & 0 & \\
\hline 宝城吳氏 & & 0 & & & & & & 0 & & & \\
\hline 仁同張氏 & & 0 & & 0 & & & O & 0 & 0 & & 0 \\
\hline 南陽洪氏 & & 0 & 0 & & & & & 0 & & 0 & \\
\hline 平山申氏 & & 0 & 0 & & & & & 0 & 0 & 0 & \\
\hline 恩津宋氏 & & & & & 0 & & & 0 & 0 & 0 & \\
\hline 䍜興閏氏 & & 0 & & & & & & 0 & & 0 & \\
\hline 漢陽趙氏 & & 0 & & & & & 0 & 0 & & 0 & 0 \\
\hline 達城徐氏 & & & & & & & & 0 & & 0 & \\
\hline 海州吳氏 & & & & & & & & 0 & & & \\
\hline 延日鄭氏 & & & & & & 0 & & 0 & & & \\
\hline 韓山李氏 & 0 & & & & & & & 0 & & & \\
\hline 全州崔氏 & & 0 & & & & & & 0 & & 0 & \\
\hline 済州高氏 & & 0 & 0 & & & & 0 & 0 & & & \\
\hline 宜寧南氏 & & 0 & & & & & & 0 & & 0 & \\
\hline 谷山延氏 & & 0 & 0 & & & & & 0 & 0 & 0 & \\
\hline 全義李氏 & & 0 & 0 & & & & & & 0 & & \\
\hline 慶州鄭氏 & & & & & & & & 0 & & & \\
\hline 忠州池氏 & & 0 & & & & & 0 & 0 & 0 & 0 & \\
\hline 丹陽禹氏 & & & & & 0 & & & 0 & 0 & & \\
\hline 扶安林氏 & & 0 & & & & & & 0 & & & \\
\hline 密陽孫氏 & & 0 & & & & & O & & & & \\
\hline 江陵俞氏 & & & & & & & & & & & \\
\hline 水原白氏 & & & & & & & & 0 & & 0 & \\
\hline 義城金氏 & & & & & & & & 0 & 0 & 0 & \\
\hline 延安李氏 & & & 0 & 0 & & & & 0 & & & \\
\hline 南原梁氏 & & & & & 0 & & 0 & 0 & & & \\
\hline 清風金氏 & & 0 & 0 & 0 & & & & 0 & & & \\
\hline 㫋善全氏 & & & & & & & & 0 & & & \\
\hline 交河盧氏 & & 0 & & & & & & 0 & & & \\
\hline 昌寧恵氏 & & & & & & 0 & & 0 & & & \\
\hline 江陵金氏 & & & & 0 & & & & 0 & & & \\
\hline 河東鄭氏 & & 0 & & & & 0 & 0 & 0 & 0 & & \\
\hline 草溪卡氏 & & & 0 & & & & & & 0 & & 0 \\
\hline
\end{tabular}

金海金氏は同姓同本でありながら，始祖が異なる 2 集団に区別されるが，市誌などに区別されずに掲載される 場合があったため，この表では金海金氏を一つにまとめて表示した．南陽洪氏あ同様である.

紙面上の都合により，人口順位が高い順に 50 集団を抜粋した.

(善生 (1935), 道誌, 各市・郡誌, 聞取り調査により作成). 
表 2 清州市の血縁組織と同族集落の立地

Table 2 Locations of kinship associations in Cheongju and lineage villages

\begin{tabular}{|c|c|c|c|}
\hline 血縁組織名 & $\begin{array}{c}\text { 清州 } \\
\text { 市 }\end{array}$ & \begin{tabular}{|c} 
清原 \\
郡
\end{tabular} & $\begin{array}{l}\text { 忠清 } \\
\text { 北道 }\end{array}$ \\
\hline $\begin{array}{l}\text { 順天朴氏大司憲公派宗会 } \\
\text { 文化柳氏文平派家族宗親会 } \\
\text { 坡平尹氏新鳳宗会 }\end{array}$ & $\begin{array}{l}0 \\
0 \\
0\end{array}$ & $\begin{array}{l}0 \\
0\end{array}$ & $\begin{array}{l}0 \\
0 \\
0\end{array}$ \\
\hline 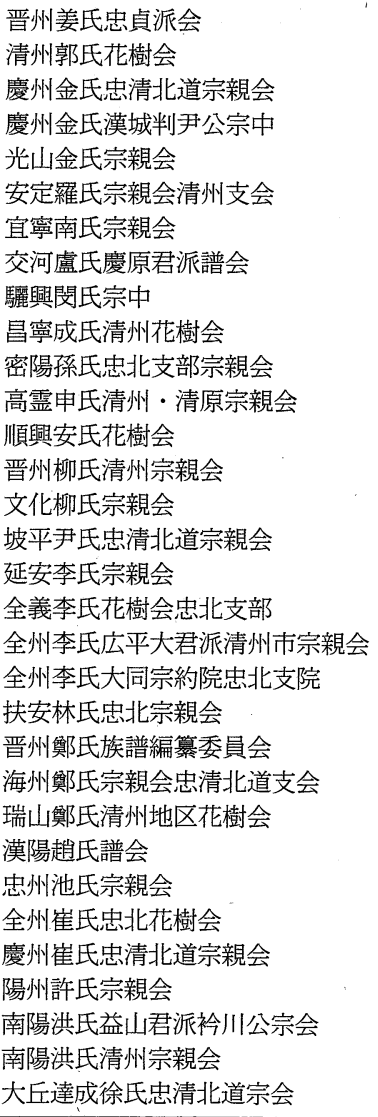 & & $\begin{array}{l}0 \\
0 \\
0 \\
0 \\
0 \\
0 \\
0 \\
0 \\
0 \\
0\end{array}$ & $\begin{array}{l}0 \\
0 \\
0 \\
0 \\
0 \\
0 \\
0 \\
0 \\
0 \\
0 \\
0 \\
0 \\
0 \\
0 \\
0 \\
0 \\
0 \\
0 \\
0 \\
0 \\
0 \\
0 \\
0 \\
0 \\
0\end{array}$ \\
\hline
\end{tabular}

忠清北道の欄には, 清州市・清原郡を除く市・郡に同 族集落が存在した場合に記した。

(『忠北・清州市・清原郡電話番号簿業種編』の 1997 年 9 月版および 2001 年 9 月版, 善生 (1935), 道誌, 各市・郡誌, 聞取り調査により作成)

織の一つである花樹会を事例として，都市の血縁組 織の形成と変容を考察する.

全州崔氏の花樹会はソウルの中央花樹会をはじめ, 広域市・道を単位とする花樹会と市・郡単位の花樹 会から構成されている. 中央花樹会は, 1956 年に ソウルに居住する全州崔氏数人らが親睦契 6) の形
表 3 清州市の血縁組織（1999・2001 年）

Table 3 Type of kinship associations in Cheongju (1999 and 2001)

\begin{tabular}{|c|c|c|c|}
\hline \multicolumn{2}{|c|}{ タイプ } & $\mathrm{A}$ & B \\
\hline \multicolumn{2}{|c|}{ 組織数 } & 3 & 8 \\
\hline 同族集落の立地 & $\begin{array}{l}\text { 清州市内 } \\
\text { 清州市外 }\end{array}$ & 3 & 8 \\
\hline 形成時期 & $\begin{array}{l}20 \text { 世紀以前 } \\
1945 \text { 年以降 }\end{array}$ & 3 & 8 \\
\hline 形成時の目的 & $\begin{array}{l}\text { 宗事事業 } \\
\text { 親睦の深化 }\end{array}$ & 3 & 8 \\
\hline 現在の活動内容 & $\begin{array}{l}\text { 宗事事業 } \\
\text { 親睦の深化 } \\
\text { 相互扶助 }\end{array}$ & $\begin{array}{l}3 \\
2\end{array}$ & $\begin{array}{l}8 \\
6 \\
4\end{array}$ \\
\hline 加入条件 & $\begin{array}{l}\text { 同姓同本 } \\
\text { 同姓同本同派 }\end{array}$ & 3 & 8 \\
\hline 加入義務 & $\begin{array}{l}\text { 義務 } \\
\text { 任意 }\end{array}$ & 3 & 8 \\
\hline 運営費用 & $\begin{array}{l}\text { 共有財産 } \\
\text { 会費 }\end{array}$ & 3 & 8 \\
\hline
\end{tabular}

数値は件.

活動内容は複数回答.

形成時期の A の内訳は，15世紀，16 世紀，19 世紀であった.

一方, B の内訳は $1945 \sim 1950$ 年が 1 件, 1951 1960 年が 2 件, $1971 \sim 1980$ 年が 3 件, 1981 年以 降が 2 件であった.

(1999 年, 2001 年の聞取り調査により作成).

式で始めた組織であった（表 4)。その後,このよ うな血縁組織はソウル以外の都市にも形成されてい った. 1970 年代に入るとソウルの中央花樹会と地 方の花樹会との連絡や交流が活発になり，1978年 には中央花樹会を中心とする全国的な組織となり， 一地方の血縁組織にすぎなかった忠清北道花樹会 (以後, 忠 北花樹会) は全国組織の下部組織に編成 される. 1997 年には, 全州崔氏の花樹会は韓国全 土 31 カ所までに広がった7).

2. 忠北花樹会の形成と成長

忠北花樹会は, 1972 年に陰城郡遠”南面”助手村里 （図 1）に居住する摧 翼”初8）と清州市居住者 20 人ほどが中心となって清州市で形成された. 形成時 の目的は同族集落と都市転入者との情報交換や都市 
表 4 全州崔氏花樹会の動向（1956～1992 年）

Table 4 Trends in the Jeonjuchoi kinship association (1956-1992)

\begin{tabular}{|c|c|}
\hline 年 & 事項 \\
\hline 1956 & ソウル花樹会の形成 \\
\hline 1969 & 水原花樹会の形成 \\
\hline 1972 & 忠北花樹会の形成 \\
\hline 1978 & 全国花樹会の形成 \\
\hline 1979 & $\begin{array}{l}\text { 京畿道花樹会の形成 } \\
\text { 全羅北道花樹会の形成 }\end{array}$ \\
\hline 1981 & 陰城高校にて忠北花樹会初代会長の石碑建立 \\
\hline 1984 & 江原道花樹会の形成 \\
\hline 1986 & $\begin{array}{l}\text { 扶安郡花樹会の形成 } \\
\text { ソウル花樹会, 区単位に分会の形成 } \\
\text { 会報の同族集落への一括送付から個人送付に変更 } \\
\text { 安養・始興花樹会の形成 } \\
\text { 清州・清原花樹会, 忠北花樹会長の下, 全国組織 } \\
\text { に編入 } \\
\text { 忠北花樹会, 祖先祭祀の参加者用に貸切バスの手 } \\
\text { 配 } \\
\text { 鉄原花樹会の形成 }\end{array}$ \\
\hline 1989 & 大田市花樹会の形成 \\
\hline 1990 & $\begin{array}{l}\text { 忠北花樹会, 任員改選の実施 } \\
\text { 会報にて清州・清原花樹会の親睦活動紹介 } \\
\text { 会報にて清州・清原花樹会の祖先祭祀の補助活動 } \\
\text { 紹介 }\end{array}$ \\
\hline 1991 & 第 1 回青少年夏季教養修練会の開催 \\
\hline 1992 & 高敞郡花樹会の形成 \\
\hline
\end{tabular}

(『全州崔氏花樹会報』により作成).

転入者同士の情報交換, 親睦の深化であったとされ る. しかし, 同族集落居住者と清州市居住者とが協 力し合って形成されたことから, 当初の機能は同族 集落と都市居住者との連絡の役割が強かったと考え られる. 忠北花樹会の会員数は次第に増加し，1982 年には 91 人に達し, 形成時から 10 年で 5 倍近くの 増加をみせた9).

1982 年当時の会員の出身地は陰城郡 30 人, 次い で清原郡 23 人と二つの地域が大方を占めており， 忠北花樹会はこの二つの地域からの転入者たちを会 員として成長したことがわかる（図 3)。中でも， 助村里の同族集落出身者が 21 人を占めた. この時 期における忠北花樹会への加入は，都市転入者にと って見知ら奻地で商いを有益に営むことに役立っ ていた。 たとえば花樹会会員に自分の商売を宣伝し， 会員がその店で優先的に商品を購入していたとされ

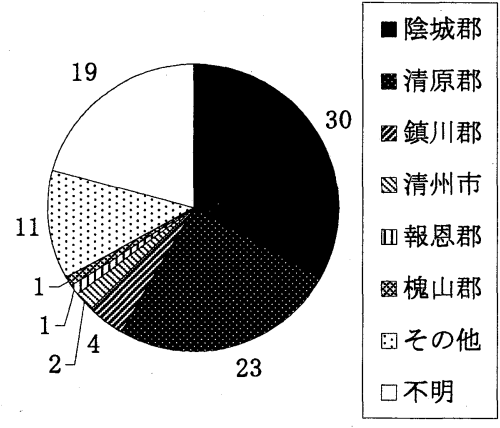

図 3 忠北花樹会会員の出身地 （1982 年）

陰城郡出身者の中, 21 人が助村里出身者. (『全州崔氏清州・清原花樹会名簿』の 1982 年版により作成).

Fig. 3 Hometowns of members of the Jeonjuchoi kinship association in Chungcheong-buk-do (1982)

る 10)。このため, 1982 年の会員の職業をみると, 会社経営者 3 人をはじめとして, 自営業者が 14 人 あ存在した（表 5).さらに 1982 年の会員の年齢は, $50 \sim 60$ 歳代を中心に, $30 \sim 50$ 歳代の壮年層の占め る割合が高かった（図 4).

3. 忠北花樹会の分化と清州・清原花樹会の機能 清州・清原花樹会は 1980 年代初頭に形成され, 1986 年, 当時の忠北花樹会会長が中心になり, 忠 北花樹会の下に全国組織の中に組み込まれた11) （表 4)，清州・清原花樹会は月に 1 度の食事を伴っ た会合を催したり，年に 1 度，旅行 12）を催したり と清州市および清原郡居住者の親睦の深化を目的と している.

全国的な組織の中に組み込まれた後になる 1992 年の会員数は 84 人であったが，1999 年にはその半 数近くの 44 人まで減少した (図 4). 会員の主な年 齢層も，1992 年では 50〜70 歳代が中心であったが, 1999 年現在では 60 歳代以上が中心になり, 会員数 の半数以上を占める. 一方, $30 \sim 50$ 歳代の壮年層 は年を経るごとに減少し，1999 年には 50 歳代の 3 
表 5 全州崔氏忠北花樹会会員の職業（1982 年)

Table 5 Occupations of the Jeonjuchoi kinship association members in Chungcheongbuk-do (1982)

\begin{tabular}{l|l|c}
\hline \multicolumn{2}{|c|}{ 職業区分 } & 人 \\
\hline 公務員 & 管理的公務員 & 17 \\
\hline 専門職 & 教員 & 6 \\
& 医師 & 2 \\
\hline \multirow{2}{*}{ 会社員 } & 商品販売従事者 & 5 \\
& 販売類似職業従事者 & 6 \\
& 会計事務従事者 & 2 \\
& その他のサービス職業従事者 & 1 \\
& 食料品製造従事者 & 1 \\
& 定置機関・機械・建設機械運転従事者 & 1 \\
\hline \multirow{2}{*}{ 自営業 } & 会社・団体等役員 & 3 \\
& 商品販売従事者 & 5 \\
& 販売類似職業従事者 & 1 \\
& 精穀・製粉・調味食品製造従事者 & 1 \\
& その他の製造・制作従事者 & 1 \\
& 一般機械器具組立・修理従事者 & 1 \\
& 建設躬体工事従事者 & 1 \\
& 林業従事者 & 1 \\
\hline \multirow{2}{*}{ 不明 } & & 36 \\
\hline
\end{tabular}

(『全州崔氏清州・清原花樹会名簿』の 1982 年版により 作成).

表 6 全州崔氏清州・清原花樹会員の年度別転入理 由 $(1999 \cdot 2001$ 年)

Table 6 , Reason why the members of Jeonjuchoi kinship association in Cheongju and Cheongwon-gun have moved to Cheongju (1999 and 2001)

\begin{tabular}{|c|c|c|c|c|c|c|}
\hline & $\begin{array}{c}1945 \\
\sim \\
50 \text { 年 }\end{array}$ & $\begin{array}{c}1951 \\
\sim \\
60 \text { 年 }\end{array}$ & $\begin{array}{c}1961 \\
\sim \\
70 \text { 年 }\end{array}$ & $\begin{array}{c}1971 \\
\sim \\
80 \text { 年 }\end{array}$ & $\begin{array}{c}1981 \\
\sim \\
90 \text { 年 }\end{array}$ & $\begin{array}{c}1991 \\
\sim\end{array}$ \\
\hline $\begin{array}{l}\text { 進学 } \\
\text { 就職 } \\
\text { 子女教育 } \\
\text { 子弟との同居 } \\
\text { その他 } \\
\text { 不明 }\end{array}$ & 1 & $\begin{array}{l}1 \\
1\end{array}$ & 3 & $\begin{array}{l}2 \\
4\end{array}$ & $\begin{array}{l}2 \\
1 \\
1\end{array}$ & $\begin{array}{l}2 \\
1\end{array}$ \\
\hline 計 & 1 & 5 & 3 & 6 & 4 & 3 \\
\hline
\end{tabular}

数值は人数.

30 人のうち, 転居歴のない 8 人を除く.

(1999 年, 2001 年のアンケートにより作成).

人のみになっている.これは清州・清原花樹会の会 員の多くが壮年層であり仕事を持っていたため，月 に 1 度の会合への参加は負担となり, 年を経るごと

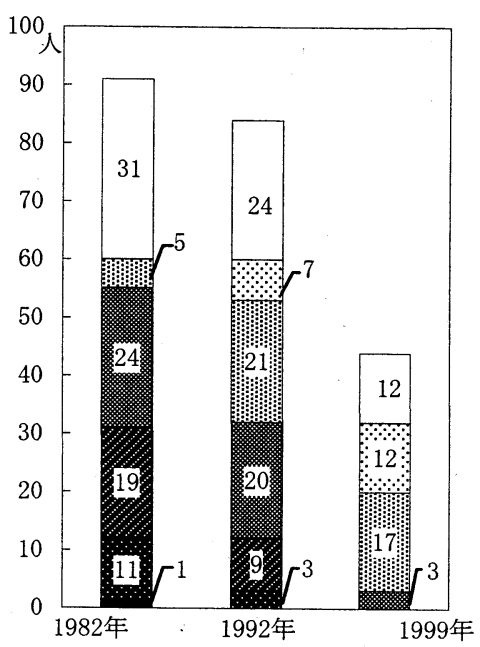

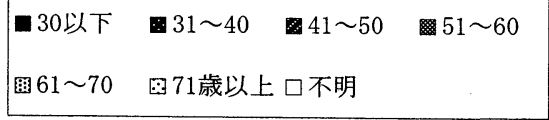

図 4 全州崔氏清州・清原花樹会会員の 年齢構成の変化

(『全州崔氏清州・清原花樹会名簿』の 1982 年版, 1992 年版, 1999 年版より作成).

Fig. 4 Change in members' age composition in the Jeonjuchoi kinship association in Cheongju and Cheongwon-gun

に会員は減少，年齢層も上がったと考えられる.

また清州・清原花樹会会員の時期別の清州市への 転入理由をみると 13$) ， 1950$ 年代の転入理由は自身 の大学などへの進学であった（表 6)。しかし 1960 〜1970 年代になると, 進学のための転入はなくな り, 子女教育や求職などの理由で清州市に転入して いる. 1980 年代以降になると，子弟之の同居を目 的とした転入が加わるようになった。つまり会員の 年齢層上昇の一因として，新たに加入する会員がす でに高年齢であることも挙げられる.

このような会員の属性の变化は, 花樹会の機能に 屯影響を与えていると考えられる，つまり，形成時 の忠北花樹会は, 同族集落と都市居住者之の連絡機 能はもちろん，会員となった清州市への転入者が若 壮年層であったため, 新しい土地での住居地や職業 
の斡旋などの都市定着支援などの機能が求められた。 これらの機能は, 会員の高齢化に伴い弱体化したが, 現在の花樹会からもこの機能の一端をうかがい知る ことができる. A 氏（1938 年生まれ）は清原郡出 身者で, 1950 年代初めに中学への進学のため清州 市へ転入した。 その後清州市で教職に就き, 定年退 職後の 2001 年には故郷の清原郡北二而に再び住居 を移し，それを機に清州・清原花樹会を通して，清 原郡北二面にある会員の農地を借りて農業を営んで いる。 また 1999 年に清州・清原花樹会会長を務め た B 氏（1935 年生まれ）は，教師，警察官などの 職業を経て現在は不動産業を営み, 花樹会会員への 家屋斡旋を行っている.

以上のように会員が高齢化した現在においても, 微力ながら花樹会が有してきた都市定着支援の機能 は残存しており，若壮年層の割合が高かった 1980 年代においては，これらの機能はさらに活発に働い ていたと推察される.この結果, 忠北花樹会は会員 数を大幅に増加させ，新たに清州・清原花樹会を形 成するに至ったと考えられる。

しかし次第に会員は高歯化し，これに伴い会員の ニーズあ変化した．C氏（1916年生まれ）は 垫清南道羿安市出身で, ソウルに居住していた。 清州市に居住する子弟と同居するため, 1998 年清 州市に転入した．C 氏はソウル居住時に中央花樹会 に加入しており, 清州・清原花樹会の存在は転入以 前から知っていた，そこで，C 氏は清州市に転入す るとすぐに，清州・清原花樹会にも加入した．転入 して日が浅いC氏にとって, 清州・清原花樹会の 月に 1 度の会合は清州市において知人を作る貴重な 機会であり，会合を楽しみにしている。このように 子弟との同居を主な目的とする高齢者の新会員にと って, 新しい土地での職業や住居地の斡旋などの必 要性は低いが, 新たに知人を得る機会が少ない問題 が出現する、そこで清州・清原花樹会は高齢者の新 会員にとって知人を得る機会を提供することで, 高
齢者の新しい環境への恐れを緩和するという高齢者 向けの新たな都市定着支援の機能に变容したのでは ないかと考えられる．同様に高齢者の既存会員にと ってあ職業や住居地の斡旋などの必要性は低く，こ のため会員間の親睦が清州・清原花樹会の中心的機 能として顕在化したすのと思われる.

清州・清原花樹会への加入は, アンケート調查に より, 会員 30 人中 16 人が親戚から紹介を得て入会 したことが明らかになった。ほかに知人の紹介や会 報をみて入会した会員もいたが，いずれす 1 人ずつ と少数であった，現在では，市街地で偶然に看 板 14)をみかけた，あるいは人づてに聞くなどして 花樹会の存在を知り, 興味を抱いて花樹会に加入し た例むある.

\section{4. 全州崔氏の同族集落}

忠清北道に抢ける全州崔氏の同族集落は, 鎮川 郡，陰城郡，清原郡に存在する（表 1)。ここで取 り上げる助村里の同族集落はその中の一つであり, 清州市からは約 $28 \mathrm{~km}$ に位置する(図 1)。助村里 の同族集落の形成は䨂 純爵15)の12 代目の孫に あたる人物が漢城（現在のソウル）より来住し，こ こに同族集落を構えるようになったといわれる（陰 城郡誌編纂委員会 1996).

助村里の村落形態は宗孫16）の家を中心にした集 村であるが，現在では多くの空き家がみられ，村内 の小学校が近年廃校となるなど，高龄化が進んでい る. 助村里を含む遠南面の人口は，1970 年以降急 激に減少傾向を示し, 2000 年には 3,591 にまで減 少した (図 5). 助村里の人口減少の要因は, 都市 への求職や進学を目的とする若壮年層の転出が大き いが，1980 年代の遠南貯水池の建設により，建設 予定地の居住者が退去したためでああるという.

助村里の血緑組織は，約 400 年前に形成されたと いわれ，現在も同族集落に居住する宗孫を中心に族 譜編纂や祖先祭祀などの活動を行っている．祖先祭 


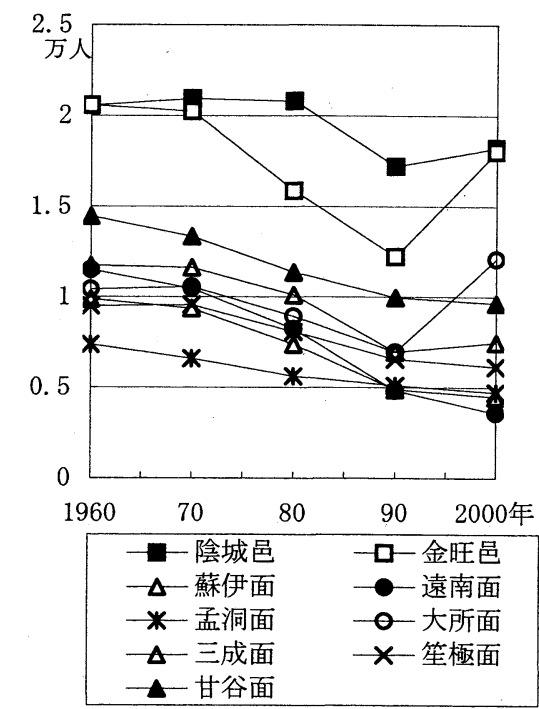

図 5 陰城郡の人口推移 $(1960 \sim 2000$ 年) 1960 年に 104 人, 1970 年に 14 人の面が不詳. (1960 年は『人口住宅国政調查』, 1970 年以降 は『総人口と住宅調査報告』により作成).

Fig. 5 Population change in Eumsong-gun (1960-2000)

祀に関わる出来事は，たびたび花樹会の会報に取り 上げ紹介される(表 4 )。特に助村里内にある 仁孝蔳 17) の創建は，同族集落の血縁組織だけでは なく，忠北花樹会などの協力があったという.

\section{IV韓国の都市と血縁組織}

以上，地方都市清州市における血縁組織の形成と 変容を, 全州崔氏の血縁組織を事例に明らかにした. 以下，この点を踏まえ，清州市の血縁組織の特性に ついて若干の予察をする。

清州市の血縁組織は，同族集落との関係から分類 すると，清州市以外の同族集落からの転入者たちに よって新たに形成された B タイプが大半であった。 形成時期は清州市の人口増加が顕在化した 1970 年 代以降である.

ここで韓国全体の都市人口と都市人口率の推移を 考慮した場合，洪（1981）によれば，1946年，都 市人口は韓国全人口約 1936 万中，わずかに約 283
万（約 14\%）にすぎなかったが，1970 年には韓国 全人口約 3146 万中, 約 1295 万（約 41\%）まで成 長し, 1980 年, 都市人口は韓国全人口約 3743 万人 中，約 2143 万（57\%）之郡人口の割合は逆転する に至った。

したがって，1970 年代以降，清州市以外の都市 であ $\mathrm{B}$ タイプのような血縁組織が形成される現象 は全国的な傾向であると推察される．全州崔氏の血 緑組織の事例でも，清州市だけでなく全国各地に血 縁組織が形成されたことから明らかである。このよ うな動向の中で, 韓国の地方都市に形成された血縁 組織のネットワークは，その都市とおのおのの同族 集落とを結ぶように形成されたが，全州崔氏の忠北 花樹会が 1978 年にソゥルの中央花樹会の下に全国 組織に編成されたように，ソウルの血縁組織を中心 に整備され，都市間のネットワークあ体系化されて いったと考えられる.

形成の目的は族譜編纂などに必要とされる都市転 入者の情報収集など，宗事の補助的な役割を果たす ためであった. しかし全州崔氏の血縁組織において, 血縁組織の加入が清州市での商いに有利に作用した 点や会員が高歯化した現在であ住居地や職業の斡旋 などの機能を有している点, 清州市のほかの血縁組 織においてむ, 活動内容に転入者への職業や住居地 の斡旋が含まれている点から，清州市の血縁組織が 都市転入者のための都市定着に対する支援的な機能 あ包含していたと推察される。

このような機能により, 清州市の血縁組織は都市 転入者を会員として成長していった。清州市の血縁 組織は，会員である都市居住者が増加するに従い， 都市居住者のニーズに応じ, 組織の分化が行われた. その結果，全州崔氏の血縁組織である忠北花樹会は, 清州市および周辺の清原郡居住者を対象とし，都市 居住者間の親睦の深化を目的とするさらなる清州・ 清原花樹会という下部組織に分化した。このような 現象は，魯（2000）がソウルに拈いて実証している 
ように，清州市のみならず，ほかの都市においても 発生していることが想定される.

全州崔氏の血縁組織は分化した後, 会員の減少お よび会員の年齢層が高齢化し，このため血縁組織の 機能も高齢者のニーズ向けに変容している.これに 対し, 若壮年層の転入著しい大都市の血緣組織では, つねに転入者の新しい環境への支援が期待され，清 州市の血縁組織とはまた違った機能が付加され，さ まざまな会員のニーズに対応していることが予察さ れる，血縁組織の社団法人化や，同姓異本などの血 縁組織の形成といった現象は，これを受けての動向 であると考えられる。

また清州市の血縁組織は, 大丘達成徐氏忠清北道 宗会を除いて，すべてが同姓同本の血縁組織である (表 2)。これは清州市の血縁組織の多くは，清州市 周辺の清原郡に同族集落の存在する割合が高いこと と関係する。したがって，さまざまな地域からの転 入者が多い大都市の場合，これに該当せず，同姓同 本以外の血縁組織屯多く存在し, 清州市の血縁組織 とは異なる形成と変容を経験していることも予察さ れる.これらの点は, 大都市を事例として明らかに していく予定である.

\section{V おわりに}

1945 年以降, 韓国では都市への人口集中が始ま るが，本格化するのは 1960 年代以降である。 1960 年代になると, 都市への人口集中が加速し, 特に人 口集中が著しい首都ソウルでは村落からの転入者に よって血縁組織が形成された。この時期には地方都 市の清州市への転入者もいたが, 村落から清州市へ の転入者が増加するのは, やや遅れて 1970 年以降 である。これは政府の地方工業育成策により, 清州 市に工業団地が設立され，清州市周辺地域はむちろ ん, 忠清北道や忠清南道から求職者の転入が増加し たことや教育機関の設立む活発になり，進学や子女 教育を目的とする転入者が増加したためである.
このような状況を背景に清州市の血縁組織は, 1970 年代に忠清北道内の同族集落汃ら清州市に転 入した経済的・社会的成功者たちを中心に，同族集 落との連絡を補うために形成された。 その後, 清州 市の血縁組織は，各同族集落加らの転入者を会員に 迎え入れ成長し, 就職や住居地の斡旋など, 転入者 の都市定着支援などの役割も果たした。さらに 2000 年代になると, 会員の高齢化が進行し, 血縁 組織は親睦を中心とする機能に变容したことを明ら かにした。

これまで韓国の血縁組織に関する研究は大都市を 研究対象地域とし, 主に血縁組織の機能分析が行わ れてきた. しかし，ソウルと地方都市における都市 発展の差異は, 血縁組織の形成期の差異を生み出し ていた。 また，地方都市の血縁組織はソウルに置か れた中央の血縁組織とのネットワークを形成してお り, 血縁組織の研究は大都市での機能分析のみでは 明らかにできない地理学的アプローチが必要とされ る.これらは, 地方中心都市の血縁組織を研究対象 としたがゆえに見出された課題であり, 今後の重要 な研究課題とされるべきである，都市の血縁組織は， その存在を確認する困難さ, 聞取り調査とアンケー 卜調査に頼らざるを得ない限界があるが, 現代韓国 の都市社会の本質を見出すためには必要不可欠な問 題である.

現地調査では, 崔 萬植氏, 崔 真栄氏をはじめ, 全 州崔氏清州・清原花樹会の会員の皆様, 助村里の同族集 落の皆様方に多大なる御協力をいただきました。また快 く聞取りに応じて下さった宗親会, 花樹会, 宗中の皆様 に深く感謝いたします.

本稿は 2001 年度茨城大学大学院に提出した修士論文 の一部である. 本稿をまとめるにあたっては, 茨城大学 教育学部の小野寺 淳先生, 東京学芸大学の古田悦造先 生に終始御指導を賜りました。 また韓国忠北大学校師範 大学に留学以来, 成 俊鏞先生, 韓 柱成先生に御指導 を賜りました. 英文要旨は, 茨城大学人文学部の葉 倩 瑋先生, 東京学芸大学の Wendy Lee Bowcher 先生に 校閲いただきました. 
茨城大学人文学部の朝野洋一先生, 韓国建国大学校理 科大学の洪 顯哲先生をはじめ, 多くの先生方々から御 教示をいただきました.ここに記して感謝の意を示しま す.なお, 本稿の骨子は 2001 年度人文地理学会大会 (神戸大学) において発表した。

（投稿 2002 年 7 月 2 日）

(受理 2005 年 3 月 5 日)

\section{注}

1）韓国では「集姓村」，「同族部落」，「同姓村」などが用 いられ, 一定した呼称は存在しないが, 善生 (1933) が 「同族部落」と称したため, 以降この用語が一般的であ る. 日本では「部落」を「集落」に修正する例が多いた め, 本稿では「同族集落」とする，ただし，韓国におけ る「同族集落」はその多くが一つの集落に複数の一族が 割拠している雑姓集落であることに注意したい.

2）韓国の血縁組織を表す言葉は, 門中, 宗中, 宗会, 宗 親会, 大宗会, 花樹会, 同族組織, 同姓組織などさまざ まなものがあり, 現在む統一された言葉は存在しない. 本研究では血縁関係にあると認識される同姓同本を基礎 とする組織から, 同姓同本ではない者を会員とする同姓 異本の組織む扱うため, 便宜上, 包括的に表現する「血 縁組織」という言葉を用いることにする.

3）長男系以外の祖先に高名な学者や大官を輩出するなど, 長男系でない子孫が優勢になると, その祖先から継続的 に分裂関係が生じる（伊藤 1977）。これを「派」といい, この「派」が同じことを指す。

4) 祖先祭祀に関わる事業で, 祖先の有徳顕彰や族譜編纂 などを行う。

5）家系に関する記録. 李朝中期に貴族の間で急速に普及 した. その背景には, 血縁思想の浸透とこれに伴う階級 や党派の形成, 祖先祭祀, 相続などの制度の確立があっ た（伊藤ほか 2000）.

6）韓国の伝統的な相互扶助組織. 日本の頼母子講にあた る.

7）全州崔氏中央花樹会 1997。『創立 40 周年記念全州崔 氏中央花樹会第 40 次定期総会』. ソウル：譜学社.（韓 国語)

8）崔 翼初氏は助村里の農家に生まれたが，中国で製粉 業を行い, 経済的な成功を収めている. その後, 先祖の 石碑・石物などの建立に積極的に賛助し, 全州崔氏忠清 北道花樹会を創立し, 初代会長として活躍した.

9） 1982 年当時, まだ忠北花樹会会員専用の名簿が作成 されておらず，また忠北花樹会と清州・清原花樹会会員 の多くが重複しているため, 清州・清原花樹会会員の名 簿が忠北花樹会会員名簿として使用されていたという.

10）前清州・清原花樹会会長の崔 萬植氏（1930 年生） により聞取り。
11）『全州崔氏花樹会報第 46 号』によれば，清州・清原 花樹会の形成は 1986 年となっているが，1982 年にはす でに清州・清原花樹会会員の名簿が存在している. また 聞取り調查に掞いても 1980 年代の初頭には清州・清原 花樹会が存在していたという。このため, 本研究では 1980 年代初頭に清州・清原花樹会が形成され，1986 年 に全国的な組織の下部組織として組み込まれたと考える.

12）韓国の各所に散在する祖先の墓を巡回し，参拝する ことを旅行の目的としている.

13）資料が存在しないため, 1999 年および 2001 年の会 員に実施したアンケート調査から，時期別の転入理由を 求めた。

14）清州・清原花樹会の会合場所になっている北門路二 街の食堂は, 1990 年頃に看板を揭げた。

15）高麗時代の㥃宗の時（1095～1105 年), 兵部尚書々 神虎衛上将軍を経て, 完山府開国伯に封じられた人物で ある。全州崔氏は 3 人の異なる人物を始祖とし，それぞ れ，文烈公派系，文成公派系，文忠公派系に分かれてい る. その中で崔 純爵は文烈公派系の始祖とされる人物 である。

16）宗孫は始祖から直系の男性長子を通して伝えられる 宗家の当主のことをいう. 宗孫の年齢が若くとも一族の 要として, 祖先祭祀では最初に香をたき酒盃を供える初 献官の役を務めるなど，血縁組織において重要な役割を 果たす (伊藤 1997).

17）有徳の人物の徳行を称えるために作られた廟を指す.

\section{文 献}

李 光奎 · 末成道男 1973 . 慶尚北道百忍 - 中浦両部落調 查予報一とくに家族・親族について。 中根千枝編『韓 国農村の家族と祭儀』41-78. 東京大学出版会.

伊藤亜人 1977. 契システムにみられる Chinhan-sai の分 析. 民族学研究 41：281-291.

伊藤亜人 1987. 韓国の親族組織における「集団」と「非 集団」. 伊藤亜人・関本照夫 ·船曳建夫編『現代の社会 人類学 1一親族と社会の構造』163-186. 東京大学出 版会.

伊藤亜人編 1997.『むっと知りたい韓国 第 2 版 1』弘文 堂.

伊藤亜人 · 大村益夫 ·梶村秀樹 - 武田幸男 $\cdot$ 高崎宗司監修 2000.『朝鮮を知る事典』平凡社.

金 枓哲 1995. 韓国における農山村の人口減少に関する 研究の動向之課題. 人文地理 47: 21-45.

金 宅圭 1974. 韓国一いわゆる同族部落をめぐる若干 の覚え書. 青山道夫 - 有地 享 - 江守五夫 - 竹田 旦 · 松原治郎編『講座家族 第 6 巻 家族 - 親族 - 同族』5674. 弘文堂.

嶋 陸奥彦 1976. 堂内の分析一一韓国全羅南道における 
事例の検討. 民族学研究 41(1)：75-90.

嶋 陸奥彦 1978. 韓国の門中と地縁性に関する試論. 民 族学研究 43(1) : 1-17.

善生永助 1933.『朝鮮の聚落 前篇』朝鮮総督府.

善生永助 1935. 『朝鮮の聚落 後篇』朝鮮総督府.

崔 在錫著, 伊藤亚人・嶋 陸奥彦訳 1979. 『韓国農村社 会研究』学生社.

鄭 還泳 1988. 韓国の人口減少農村における人口構造と 移動メカニズム—忠清北道清原郡の 3 村落の事例．東 北地理 40(1): 31-39.

魯 富子 1992. 現代韓国の都市にお打る同族結合の社会 学的研究—ソウル市の宗親会を事例に. 名古屋大学社 会学論集 13：155-182.

魯 富子 1994. 下部組織からみた同姓同本集団の結合の 一考察—載寧李氏ソウル宗親会を事例にして. 名古屋 大学社会学論集 15：231-249.

魯 富子 1997. 韓国の都市に扔ける同姓組織の全体構造 一ソウル市の「全州李氏大同宗約院」を事例にして. ソシオロジ 128: 37-54.

魯 富子 1998. ソウル市における同姓小グループの社会 的機能. 中田 実・板倉達文・黑田由彦編『地域共同管
理の現在』217-231. 東信堂.

魯·富子 2000. 韓国の都市化の展開に伴う同姓結合の生 成之変容. 吉原和男・鈴木正崇・末成道男編『〈血縁〉

の再構築——東アジアに扔ける父系出自己同姓結合』 123-151. 風響社.

服部民夫 1975 . 日本・朝鮮に打ける同族観念の比較試論 一一養子と相続を中心として。 アジア経済 16：60-72.

権 容友 1978. 清州市ノ. 都市過程. 地理学叢論 5: 100116. (韓国語)

陰城郡誌編篹委員会 1996. 『陰城郡誌』陰城郡、(韓国語)

李 光奎 1980. 都市親族組織ノ研究. 学術院 人文社会科 学編 論文集 19：349-389.（韓国語)

李 文鐘 1984 . 同族村ノ人口移動卜村落ノ変貌——青陽 郡木面新興里 7 事例二．地理学 30：77-89. (韓国語)

李 效再 1971. 『韓国研究叢書 27 都市人/親族関係』韓 国研究院．(韓国語）

忠北大学校人文科学研究所 1997. 『清州市誌〈上・下〉』 清州市。(韓国語)

洪 慶姫 1981. 『都市地理学』.ソウル：法文社.（韓国 語) 


\title{
Formation and Transformation of Kinship Associations in Cheongju, South Korea: A Case Study of the Jeonjuchoi Kinship Association
}

\author{
SAITO Kumi (Graduate student, Tokyo Gakugei University)
}

The purpose of this study is to examine the formation and functional changes in kinship associations in Cheongju, a local city in South Korea. The formation and changes in kinship associations are closely related to rural-urban migration.

The population of South Korea became concentrated in the cities after 1960. Migrants actively formed new kinship associations in major cities, such as Seoul. Kinship associations in Cheongju have been formed since the 1970 s due to a remarkable increase in the population of that city. People who achieved economic and social success in the city developed strong connections with lineage villages of Chungcheong-buk-do. Thus, kinship associations in cities grew by accepting migrants from the lineage villages. The associations helped newcomers to settle in the city because they were able to introduce jobs and places to live. Kinship associations are being reformed and reorganized in accordance with the population growth and people's demands in urban areas.

Key words: South Korea, Cheongju, kinship association, lineage village 